\title{
Soluble expression of an amebic cysteine protease in the cytoplasm of Escherichia coli SHuffle Express cells and purification of active enzyme
}

Ekaterina Jalomo-Khayrova', Rosa E. Mares', Patricia L. A. Muñoz', Samuel G. Meléndez-López', Ignacio A. Rivero ${ }^{2}$ and Marco A. Ramos ${ }^{1 *}$

\begin{abstract}
Background: Recombinant production of amebic cysteine proteases using Escherichia coli cells as the bacterial system has become a challenging effort, with protein insolubility being the most common issue. Since many of these enzymes need a native conformation stabilized by disulfide bonds, an elaborate process of oxidative folding is usually demanded to get a functional protein. The cytoplasm of E. coli SHuffle Express cells owns an enhanced ability to properly fold proteins with disulfide bonds. Because of this cellular feature, it was possible to assume that this strain represents a reliable expression system and worthwhile been considered as an efficient bacterial host for the recombinant production of amebic cysteine proteases.

Results: Using E. coli SHuffle Express cells as the bacterial system, we efficiently produce soluble recombinant EhCP1 protein. Enzymatic and inhibition analyses revealed that it exhibits proper catalytic abilities, proceeds effectively over the substrate (following an apparent Michaelis-Menten kinetics), and displays a typical inhibition profile.

Conclusions: We report the first feasibility study of the recombinant production of amebic cysteine proteases using $E$. coli SHuffle Express as the bacterial host. We present a simple protocol for the recombinant expression and purification of fully soluble and active EhCP1 enzyme. We confirm the suitability of recombinant EhCP1 as a therapeutic target. We propose an approachable bacterial system for the recombinant production of amebic proteins, particularly for those with a need for proper oxidative folding.
\end{abstract}

Keywords: Recombinant protein, Amebic cysteine protease, Expression and purification, Cytosolic oxidative folding, Proteolytic activity, Enzyme inhibition

\section{Background}

Proteases are hydrolytic enzymes that cleave the peptide bond that joins amino acids in proteins [1,2]. Based on the cleavage site at the substrate, they are usually subdivided into exopeptidases and endopeptidases [1, 3]. However, according to their catalytic mechanism and the amino acid residue present at the active site, are so grouped in aspartic proteases, cysteine proteases, glutamic proteases, metalloproteases, asparagine proteases,

\footnotetext{
*Correspondence: mramos@uabc.edu.mx

${ }^{1}$ Facultad de Ciencias Químicas e Ingeniería, Universidad Autónoma de Baja California, Calzada Universidad 14418, Parque Industrial Internacional, 22390 Tijuana, BCN, México

Full list of author information is available at the end of the article
}

serine proteases, threonine proteases, and proteases with mixed or unknown catalytic mechanism [4]. Because of their biochemical function play significant roles in several processes that are critical for cell life, such as degradation of potentially toxic misfolded or damaged polypeptides [5].

Worldwide, protozoan parasites infectious to humans represent a major threat to public health $[6,7]$. Intracellular parasites, such as Toxoplasma, Leishmania, Plasmodium, and Trypanosoma, are among the most lethal [8]. Cryptosporidium, Entamoeba, and Giardia infect the gastrointestinal tract causing diarrhea, which is fatal if left untreated [9], while Trichomonas colonizes 
the epithelium of the urogenital tract producing inflammation in the cervix, vagina, and urethra [10]. These pathogens encode a variety of proteases involved in essentially all aspects of their biology, including (i) cell invasion, development, and migration, (ii) evasion of host immune system, and (iii) degradation of proteins for nutrition [11, 12]. Thus, these proteolytic enzymes have medical and pharmaceutical importance as they are valuable targets for designing novel or improved therapeutic compounds [3, 6-10, 13-17].

Entamoeba histolytica (Eh), the causative agent of human amebiasis [18], has 86 genes encoding proteolytic enzymes: 50 cysteine proteases, 22 metalloproteases, 10 serine peptidases, and 4 aspartic proteases [19]. Of these, secreted cysteine proteases $(\mathrm{CP})$ play significant roles in pathogenicity, i.e., proteolytic degradation of host extracellular matrix components [20, 21]. Different studies have shown that the high expression levels of three enzymes: $E h C P 1, E h C P 2$, and $E h C P 5$, account for roughly $90 \%$ of the CP-specific activity [22, 23]. Interestingly, $E h \mathrm{CP} 1$ is unique to E. histolytica, since the orthologous gene is absent in E. dispar [22, 24], a morphologically undistinguishable but non-pathogenic ameba [25]. As an inactive precursor or zymogen, which comprises a prodomain that blocks the active site, depends on the cleavage of the signal peptide and the limited proteolysis of the pro-domain to get its mature form (Additional file 1: Figure S1).

To date, several recombinant approaches have been undertaken to produce EhCP proteins using Escherichia coli cells as the bacterial system [24, 26-29]. Although active enzymes were satisfactorily obtained, protein insolubility was the major challenge found, requiring an elaborate oxidative protein folding process to promote solubility. E. coli SHuffle Express, a mutant strain recently been developed and successfully proved to own an enhanced ability to correctly fold proteins with disulfide bonds in the cytoplasmic compartment [30]. Considering the foregoing, we took a chance on this bacterial system for soluble expression of recombinant $E h C P$ proteins. Here, we present efficient recombinant production of fully soluble and active EhCP1 enzyme using E. coli SHuffle Express strain as the bacterial host.

\section{Results}

First, using pQE30 as the parental vector, the recombinant pQEhCP1 plasmid (Additional file 1: Figure S2) was successfully constructed by subcloning the gene fragment encoding the pro-mature $E h \mathrm{CP} 1$ protein under the control of the $\mathrm{T} 5 / \mathrm{lacO}$ (promoter-operator) sequence. Competent E. coli SHuffle Express cells were efficiently transformed with $\mathrm{pQEhCP1}$ and recombinant protein was easily induced with $0.5 \mathrm{mM}$ isopropyl- $\beta$-D-1-thiogalactopyranoside (IPTG). After bacterial culturing for $18 \mathrm{~h}$ at $30^{\circ} \mathrm{C}$, recombinant $E h C P 1$ protein tagged with a hexahistidine sequence at the $\mathrm{N}$-terminus was readily purified by two consecutive chromatographic protocols: nickel-affinity and gel permeation. Analytical expression assays revealed proper gelatinase activity (Additional file 1: Figure S3). Furthermore, quantitative analysis of the expression and purification process showed a reasonable outcome in terms protein purity and protease activity (Table 1).

Protease activity of recombinant $E h C P 1$ was effectively measured using two synthetic peptides as substrates, Z-Arg-Arg-pNA (chromogenic) and Z-Arg-Arg-AMC (fluorogenic). While considering the $\mathrm{pH}$ value of 6.5 as standard (as maximal activity was found within 5.5 and 7.5 [24]), the assay temperature was simply decided from preliminary measurements (using the initial rate as a test indicator): $37{ }^{\circ} \mathrm{C}$ for chromogenic and $22 \pm 1{ }^{\circ} \mathrm{C}$ for fluorogenic. Since the precise amide bond at the substrate was efficiently recognized and hydrolyzed by enzymatic action, each released product (p-nitroaniline, pNA; 7-amino-4-methylcoumarine, AMC) was correspondingly monitored and used to calculate the protease activity. Depicted in Fig. 1, the enzyme concentration positively affects the rate of reaction, i.e., an increase in the recombinant EhCP1 amount improves the protease activity. Likewise, the substrate concentration stimulates the rate of reaction, and thus the protease activity (Fig. 2). Thoroughly examining the latter, using enzyme at $0.05 \mathrm{mg} / \mathrm{mL}$ (for chromogenic assay) or $0.005 \mathrm{mg} / \mathrm{mL}$ (for fluorogenic assay), we obtained sound kinetic parameters for the hydrolysis of both substrates: Z-ArgArg-pNA $(\mathrm{Km}=57.1 \mu \mathrm{M} ; \quad \operatorname{Vmax}=29.3$ units; $\mathrm{SA}=$ 5856.6 units $/ \mathrm{mg})$ and Z-Arg-Arg-AMC $(\mathrm{Km}=6.7 \mu \mathrm{M}$; $\mathrm{Vmax}=19 \mathrm{FU} / \mathrm{min} ; \mathrm{SA}=38,088 \mathrm{FU} / \mathrm{min} / \mathrm{mg}$ ).

Table 1 Purification of recombinant EhCP1 (summary)

\begin{tabular}{|c|c|c|c|c|c|}
\hline $\begin{array}{l}\text { Purification } \\
\text { Step }\end{array}$ & $\begin{array}{l}\text { Total Protein } \\
(\mathrm{mg})^{\mathrm{b}}\end{array}$ & Total Activity (units) $^{c}$ & Specific Activity (units/mg) ${ }^{c}$ & $\begin{array}{l}\text { Recovery Yield } \\
(\%)^{d}\end{array}$ & $\begin{array}{l}\text { Enzyme Purity } \\
(\%)^{\mathrm{e}}\end{array}$ \\
\hline Crude lysate $^{a}$ & 69.75 & 9918.5 & 142.2 & 100.0 & 2.4 \\
\hline Nickel-affinity & 0.81 & 4731.2 & 5841.0 & 47.7 & 97.0 \\
\hline Gel permeation & 0.65 & 3915.0 & 6023.0 & 39.5 & 100.0 \\
\hline
\end{tabular}

${ }^{\mathrm{a}}$ Obtained from five cell pellets, each from a $200-\mathrm{mL}$ batch (total: $1 \mathrm{~L}$ of bacterial culture). ${ }^{\mathrm{b}}$ Protein concentration determined by Bradford assay. ${ }^{\mathrm{c} P r o t e a s e}$ activity measured by the chromogenic assay. ${ }^{d}$ Relative amount of total activity at each step as compared to the first. ${ }^{e}$ Relative amount of specific activity at each step as compared to the last 

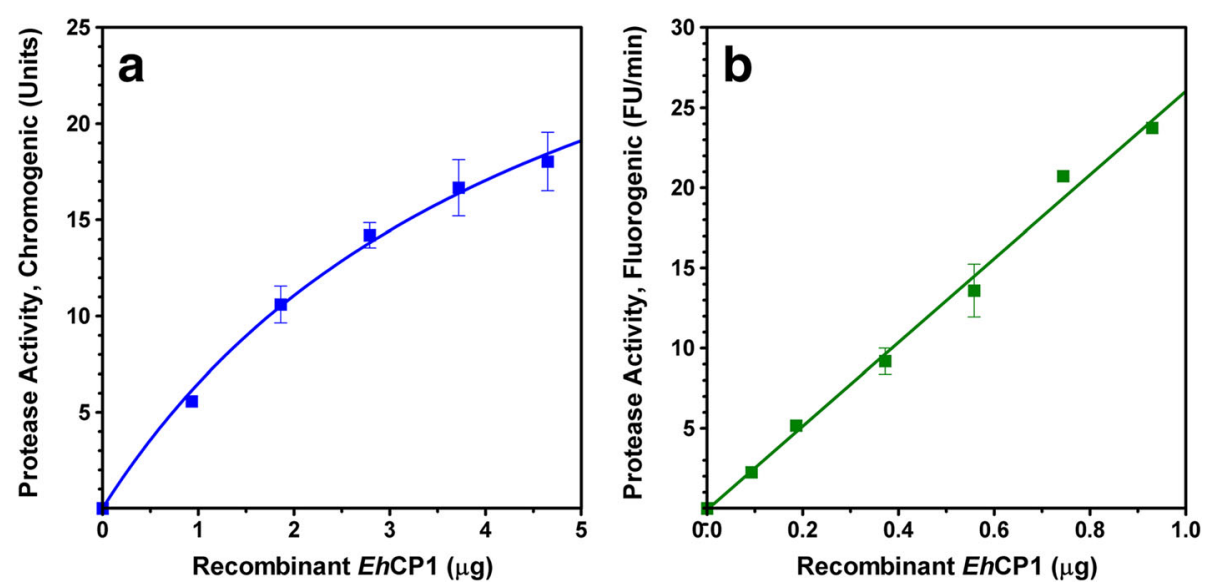

Fig. 1 Effect of the enzyme concentration on the rate of reaction. a Hydrolysis of Z-Arg-Arg-pNA by recombinant EhCP1 (0-4.65 $\mu \mathrm{g})$. b Hydrolysis of Z-Arg-Arg-AMC by recombinant EhCP1 (0-0.93 $\mu \mathrm{g})$. Data represent the mean \pm S.E.M. (bars) of 2-3 independent experiments

Proven so far, recombinant EhCP1 exhibits specific catalytic abilities, proceeds effectively on the substrate, and follows an apparent Michaelis-Menten kinetics. Finally, to assert its value as a therapeutic target, the effect of L-trans-3-carboxyoxiran-2-carbonyl-L-leucylagmatine (E-64) on the protease activity was further evaluated. E-64 is a well-known CP-specific inhibitor that functions as an effective active-site titrant [31]. Displayed in Fig. 3, the sigmoidal curve indicates that inhibition of protease activity follows a typical dose-response profile. Also, using the enzyme concentration as before (for kinetic parameters), we found the $\mathrm{IC}_{50}$ at $1 \mu \mathrm{M}$.

\section{Discussion}

We used E. coli SHuffle Express cells harboring a recombinant plasmid to produce EhCP1 protein. Along with the mature domain, the recombinant enzyme comprises the pro-domain, which is necessary for preserving its inactive state and apparently required for proper folding [28]. As compared to those reported producing an active thioredoxin-tagged protein (Trx-EhCP1) [24]: insoluble material (about $10 \mathrm{mg} / \mathrm{L}$ ) that requires optimal refolding conditions to get reliable enzymatic activity, our approach represents progress in the recombinant production of soluble and active EhCP1 protein. Even so, since a limited yield of pure protein was found $(0.65 \mathrm{mg} / \mathrm{L})$, we acknowledge the need for further studies to improve production levels. Despite the apparent dissimilarity between the calculated $\mathrm{Km}$ values for two synthetic peptides used as substrates, Z-Arg-Arg-pNA and Z-ArgArg-AMC, which was attributed to the chemical nature of the leaving group (pNA or AMC) [32], the observed value for hydrolysis of Z-Arg-Arg-AMC $(6.7 \mu \mathrm{M})$ closely resembles those reported using other recombinant enzymes, such as Trx-EhCP1 $(2 \mu \mathrm{M})$ [24] and EhCP5 $(7.29 \mu \mathrm{M})$ [33]. Also, as a protease sensitive to E-64 (a
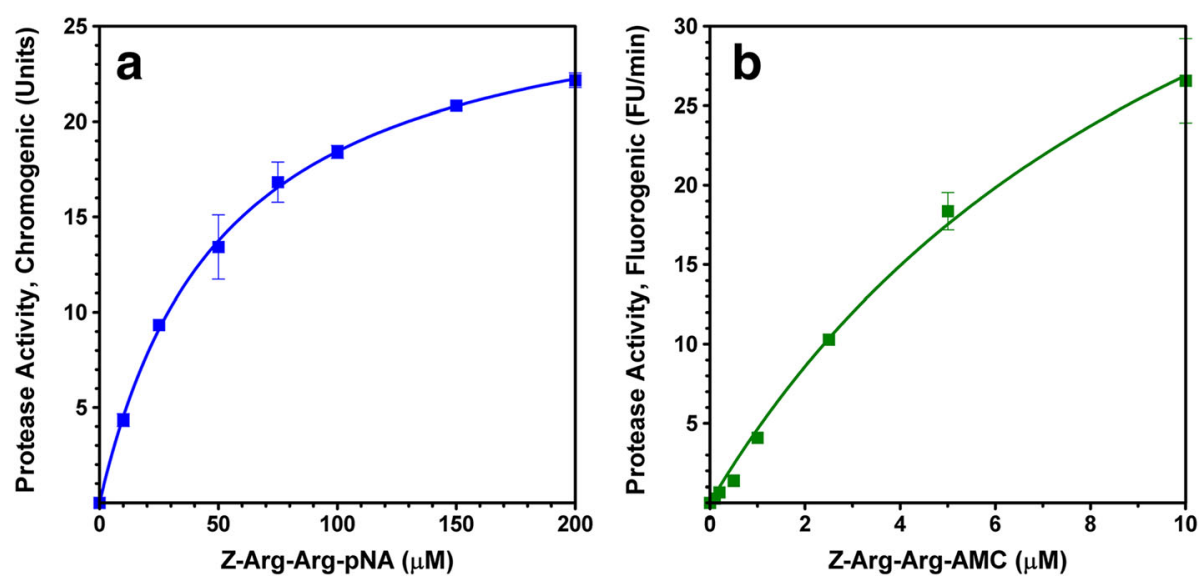

Fig. 2 Effect of the substrate concentration on the rate of reaction. a Hydrolysis of Z-Arg-Arg-pNA (0-200 $\mu$ M) by recombinant EhCP1 (0.05 mg/mL). b Hydrolysis of Z-Arg-Arg-AMC (0-10 $\mu \mathrm{M})$ by recombinant EhCP1 $(0.005 \mathrm{mg} / \mathrm{mL})$. Data represent the mean \pm S.E.M. (bars) of 3 independent experiments 

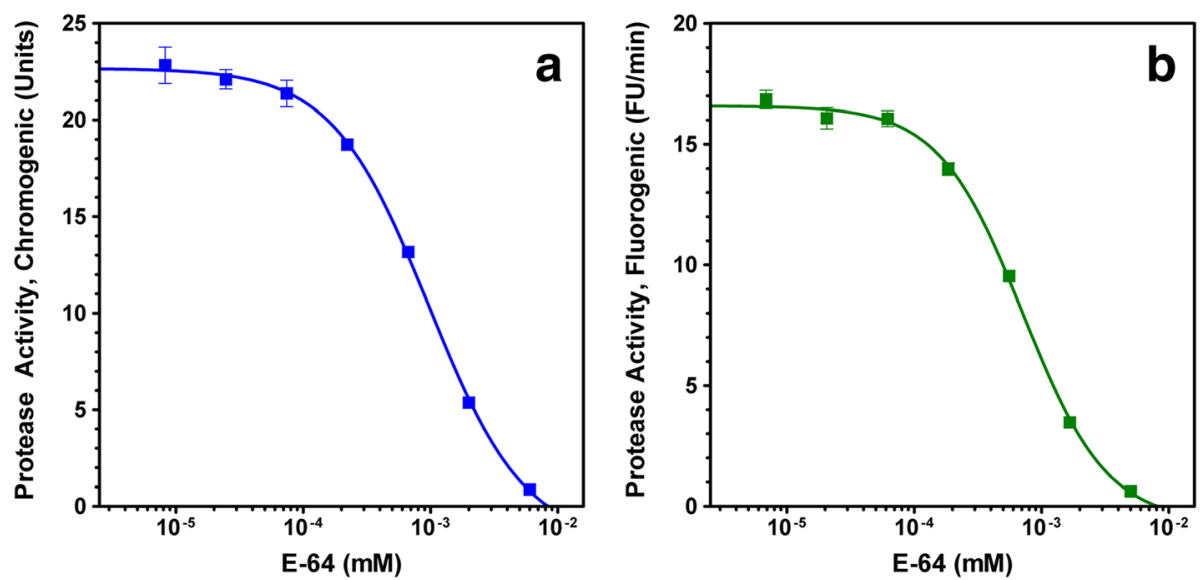

Fig. 3 Effect of the E-64 concentration on the protease activity of recombinant EhCP1. The enzyme and inhibitor (0-6 $\mu \mathrm{M})$ interact for 15 min before the assay. Hydrolysis of $200 \mu \mathrm{M}$ Z-Arg-Arg-pNA (a) and $10 \mu \mathrm{M}$ Z-Arg-Arg-AMC (b) by recombinant EhCP1 (as in Fig. 2). Data represent the mean \pm S.E.M. (bars) of 3 independent experiments

CP-specific inhibitor), it exhibits an $\mathrm{IC}_{50}$ value $(1 \mu \mathrm{M})$ comparable to that established for recombinant EhCP5 $(6 \mu \mathrm{M})$ [33]. Altogether, it is fair to presume suitability of the recombinant EhCP1 as a therapeutic target.

\section{Conclusions}

Search for new or improved compounds with therapeutic activity requires the identification and validation of targets (i.e., proteins with the potential of being blocked, inhibited, modulated or regulated, when interacting with a drug) [34]. The availability of genomic data has notably contributed towards distinguishing putative targets $[35,36]$. Since isolation and purification of proteins from their source is often a challenging task, the recombinant production using an efficient expression system represents a promising approach to get suitable material (i.e., pure and functional proteins) [36, 37].

In this study, we report the recombinant production of EhCP1 using E. coli SHuffle Express strain as the bacterial host. We present a simple protocol for the expression and purification of the recombinant protein as a soluble and active enzyme. Through the analysis of protease activity and enzymatic inhibition, we confirm its reliability as a therapeutic target. Finally, we propose an approachable bacterial cell system for the recombinant production of other amebic proteins, particularly those with a need for proper oxidative folding.

\section{Methods}

\section{Materials}

DNA amplification reagents and purification kits were acquired from Qiagen (Germantown, MD, USA). Bacterial culture medium components were obtained from Becton, Dickinson and Company (Franklin Lakes, NJ, USA). Protein analysis and purification reagents were supplied by Bio-Rad Laboratories (Hercules, CA, USA), GE Healthcare Bio-Sciences (Pittsburgh, PA, USA), and Qiagen. Endonucleases and other enzymes were available from New England Biolabs (Ipswich, MA, USA). Unless otherwise mentioned, additional reagents were provided by Sigma-Aldrich (St. Louis, MO, USA). All materials were biochemical or biotechnological research grade.

\section{Bacterial strain and plasmids}

The Escherichia coli strains and plasmids used in this study are listed in Table 2. Bacterial cultures were grown in $\mathrm{LB}$ medium (10 g/L tryptone; $5 \mathrm{~g} / \mathrm{L}$ yeast extract; $10 \mathrm{~g} / \mathrm{L} \mathrm{NaCl})$ supplemented with ampicillin $(0.15 \mathrm{mg} /$ $\mathrm{mL})$. Xl1-Blue MRF' was used as the host for molecular cloning, while SHuffle Express for protein expression.

\section{Construction of pQEhCP1}

The plasmid expressing recombinant EhCP1 was obtained by subcloning the gene fragment encoding the pro-mature polypeptide (UniProt Q01957, Ile ${ }^{14}$ to $\mathrm{Leu}^{315}$ ) into the commercially available vector pQE30. Molecular cloning was performed according to standard protocols [38]. The gene fragment was amplified by PCR from genomic DNA of E. histolytica (HM1:IMSS strain) using the synthetic primers PROEHCP1F ( $5^{\prime}$-gcg gat cca ttg att tca ata cat ggg ttg cca ata ac- $\left.3^{\prime}\right)$ and PROEHCP1R (5' -cga agc ttt cag aga tat tca aca cca gtt gga taa ag-3'), which were designed to include the BamHI and HindIII restriction sites at the 5' and 3' ends, respectively. After endonucleolytic digestion, the PCR product was inserted into pQE30. The recombinant plasmid (pQEhCP1) was extracted from transformed XL1-MRF' cells and characterized by an astringent endonucleolytic analysis. The authenticity of the insert was confirmed by DNA sequencing. 
Table 2 E. coli strains and plasmids

\begin{tabular}{|c|c|c|}
\hline $\begin{array}{l}\text { Strains or } \\
\text { Plasmids }\end{array}$ & Relevant Genotype or Features & Source \\
\hline \multicolumn{3}{|l|}{ Strains } \\
\hline XL1-Blue MRF' & $\begin{array}{l}\Delta(m c r A) 183 \Delta(\text { mcrCB-hsdSMR-mrr)173 endA1 supE44 thi-1 recA1 gyrA96 relA1 lac } \\
{\left[F^{\prime} \text { proAB lacl }{ }^{9} Z \Delta M 15 \operatorname{Tn} 10\left(\text { Tet }^{R}\right)\right]}\end{array}$ & Stratagene ${ }^{a}$ \\
\hline SHuffle Express & 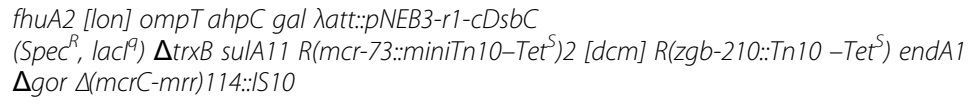 & New England Biolabs \\
\hline \multicolumn{3}{|l|}{ Plasmids } \\
\hline pQE30 & Lactose regulation, ColE1 origin, $\mathrm{Amp}^{\mathrm{R}}$ & Qiagen \\
\hline pQEhCP1 & pQE30-based, recombinant EhCP1 & This study \\
\hline
\end{tabular}

${ }^{a}$ Agilent Technologies (Santa Clara, CA, USA)

\section{Expression of recombinant EhCP1}

The recombinant EhCP1 protein was expressed in the cytosolic compartment of SHuffle Express cells harboring the pQEhCP1 plasmid. A fresh culture of transformed cells was sub-cultured (1:100) and grown at $37^{\circ}$ $\mathrm{C}$ for $2 \mathrm{~h}$ with shaking (300 rpm). Gene expression was induced by addition of IPTG to a final concentration of $0.5 \mathrm{mM}$. Expression was allowed by further growing at $30{ }^{\circ} \mathrm{C}$ for $18 \mathrm{~h}$ with shaking. Bacterial cells were harvested by centrifugation at $9300 \times \mathrm{g}, 10{ }^{\circ} \mathrm{C}$ for $10 \mathrm{~min}$. Five cell pellets, each from a $200-\mathrm{mL}$ batch, were obtained and preserved at $-20{ }^{\circ} \mathrm{C}$.

Bacterial protein extracts were prepared by cell lysis under native conditions. Each pellet was suspended in $5 \mathrm{~mL}$ of TT-L buffer (1\% Triton X-100; $100 \mathrm{mM}$ Tris$\mathrm{HCl}, \mathrm{pH}$ 8.0; supplemented with $0.2 \mathrm{mg} / \mathrm{mL}$ lysozyme) and thoroughly mixed by rocking for $5 \mathrm{~min}$. Cell lysis was achieved by sonication, using a typical procedure (10 cycles: 30 s ON, 30 s OFF; on ice bath), followed by rocking for $10 \mathrm{~min}$. The cellular debris was removed by centrifugation at $9300 \mathrm{x} \mathrm{g}$ for $15 \mathrm{~min}$ at $10{ }^{\circ} \mathrm{C}$. The supernatant (soluble fraction) was further cleared by centrifugation at $16000 \times \mathrm{g}, 10{ }^{\circ} \mathrm{C}$ for $15 \mathrm{~min}$. Protein concentration was determined by conducting a Bradford assay [39], using BSA as the standard. Protease activity was estimated by conducting a chromogenic assay [40], using Z-Arg-Arg-pNA as the substrate.

\section{Purification of recombinant EhCP1}

Under native conditions, the recombinant EhCP1 protein was purified from the cleared soluble fractions (CSF) of bacterial extracts by two consecutive standard chromatographic protocols: nickel-affinity and gel permeation. Initially diluted with one volume of BW buffer (300 mM NaCl; 100 mM Tris- $\mathrm{HCl}, \mathrm{pH} 8.0 ; 20 \mathrm{mM}$ imidazole, $\mathrm{pH}$ 8.0), CSF was then gradually loaded to a column containing nickel-nitrilotriacetic (Ni-NTA) agarose. After extensive washing, the bound protein was eluted with E buffer (300 mM NaCl; $100 \mathrm{mM}$ Tris- $\mathrm{HCl}$, pH 8.0; $250 \mathrm{mM}$ imidazole, $\mathrm{pH}$ 8.0). Fractions containing a significant concentration of pure protein (> 95\%) were pooled and slowly loaded to a PD-10 column (i.e., Sephadex G-25). Recombinant protein was eluted using $20 \mathrm{mM}$ Tris- $\mathrm{HCl}$ buffer ( $\mathrm{pH}$ 8.0). The complete purification process was monitored by SDS-PAGE [41] and gelatin zymography [42] analyses. The concentration and protease activity of recombinant EhCP1 were measured as before.

\section{Protease assays using synthetic substrates}

Enzymatic hydrolysis of Z-Arg-Arg-pNA (chromogenic) or Z-Arg-Arg-AMC (fluorogenic) was used to assess the protease activity of recombinant EhCP1. The released product, p-nitroaniline (pNA) or 7-amino-4-methylcoumarine (AMC), was properly measured as a function of time to measure the proteolytic activity. Unless otherwise mentioned, standard assays $(0.1 \mathrm{~mL})$ were as follows:

(i) Chromogenic. Conducted at $37{ }^{\circ} \mathrm{C}$, the enzyme ( $5 \mu$ g; i.e., $0.05 \mathrm{mg} / \mathrm{mL}$ ) was initially activated for $10 \mathrm{~min}$ in citrate-phosphate buffer (50 mM; pH 6.5) containing $5 \mathrm{mM}$ dithiothreitol (DTT). The reaction was started by adding the substrate $(100 \mu \mathrm{M})$ to the assay mix. The linear increment of absorbance at $415 \mathrm{~nm}\left(\mathrm{~A}_{415}\right)$ was determined from a 10-min kinetic analysis. Specific activity (SA) was expressed as units/mg (one unit is equal to 0.001 of $\mathrm{A}_{415}$ per min).

(ii) Fluorogenic. Performed at $22 \pm 1{ }^{\circ} \mathrm{C}$, the enzyme (0.5 $\mu$ g; i.e., $0.005 \mathrm{mg} / \mathrm{mL}$ ) was initially activated for $10 \mathrm{~min}$ in citrate-phosphate buffer (50 mM; pH 6.5) containing $5 \mathrm{mM}$ DTT. The reaction was started by adding the substrate $(5 \mu \mathrm{M})$ to the assay mix. The linear increment of fluorescence was determined from a 5-min kinetic analysis. Fluorescence was monitored at excitation and emission wavelengths of 355 and $460 \mathrm{~nm}$. SA was expressed as $\mathrm{FU} / \mathrm{min} / \mathrm{mg}$.

\section{Inhibition assay}

The effect of E-64 on the protease activity of recombinant EhCP1 was determined using different concentrations of the inhibitor (0 to $6 \mu \mathrm{M})$. The enzyme was 
initially incubated with the inhibitor for $15 \mathrm{~min}$ in reaction buffer without DTT. Then, this activator was added to the enzyme/inhibitor solution and after $10 \mathrm{~min}$ of additional incubation, the residual protease activity was measured as above, with a minor modification: $200 \mu \mathrm{M}$ Z-Arg-Arg-pNA or $10 \mu \mathrm{M} Z$ Z-Arg-Arg-AMC were used as the substrate.

\section{Enzyme and inhibition parameters}

$\mathrm{Km}$ values were determined by linear least squares regression fitting of reciprocal values of the initial velocity against the substrate concentration according to the Lineweaver-Burk equation. $\mathrm{IC}_{50}$ values were established by non-linear least squares regression of the protease activity against the logarithm of the inhibitor concentration according to a dose-dependent variable-slope fitting curve. Both parameters were calculated using GraphPad Prism v. 4.0 for Windows (GraphPad Software, San Diego, CA, https://www.graphpad.com).

\section{Additional file}

Additional file 1: Supplementary data. Schematic representations of the sequence coding for EhCP1 (Figure S1.) and the recombinant plasmid PQEhCP1 (Figure S2.). Analysis of recombinant EhCP1 purification (Figure S3.). (PDF $182 \mathrm{~kb}$ )

\section{Abbreviations}

AMC: 7-Amino-4-Methylcoumarine; CP: Cysteine Protease(s); E-64: L-Trans-3Carboxyoxiran-2-Carbonyl-L-Leucylagmatine; Eh: Entamoeba histolytica; EhCP1: Cysteine Protease 1 of Entamoeba histolytica; pNA: p-Nitroaniline; Z-ArgArg-AMC: Benzyloxycarbonyl-L-arginyl-L-arginine-7-amido-4-methylcoumarin; ZArg-Arg-pNA: Benzyloxycarbonyl-L-arginyl-L-arginine-p-nitroanilide

\section{Acknowledgments}

Authors thank Luciano Aldaba, Helios Gallego and Gabriela Monroy for the excellent technical assistance during the initial stages of the study.

\section{Funding}

This work was supported in part by grants from the Mexican Council for Science and Technology (CONACyT; CB-2010/01-155714 and SSA/IMSS/ ISSSTE-2011/01-161544) and the Autonomous University of Baja California (UABC; $\mathrm{CPI} / 300 / 2 / \mathrm{N} / 112 / 1)$. The founding sponsors had no role in the design of the study; in the collection, analyses, or interpretation of data; in the writing of the paper, and in the decision to publish the results.

\section{Availability of data and materials}

The datasets used and/or analyzed during the current study available from the corresponding author on reasonable request.

\section{Authors' contributions}

EJ-K performed experiments and analyzed data; REM designed experiments, analyzed data and contributed materials; PLAM and SGM-L analyzed data and contributed materials; AIR analyzed data and contributed analysis tools; MAR conceived and supervised the study, contributed reagents/materials/analysis tools and wrote the paper. All authors read and approved the final manuscript.

Ethics approval and consent to participate

Not Applicable.

\section{Consent for publication}

Not Applicable.

\section{Competing interests}

The authors declare that they have no competing interests.

\section{Author details}

${ }^{1}$ Facultad de Ciencias Químicas e Ingeniería, Universidad Autónoma de Baja California, Calzada Universidad 14418, Parque Industrial Internacional, 22390 Tijuana, BCN, México. ${ }^{2}$ Centro de Graduados e Investigación en Química, Instituto Tecnológico de Tijuana, Boulevard Industrial S/N, Mesa de Otay, 22510 Tijuana, BCN, México.

Received: 27 December 2017 Accepted: 15 March 2018 Published online: 03 April 2018

\section{References}

1. Hooper NM. Proteases: a primer. Essays Biochem. 2002;38:1-8.

2. Neitzel JJ. Enzyme catalysis: the serine proteases. Nature Education. 2010;3:21.

3. Mótyán JA, Tóth F, Tőzsér J. Research applications of proteolytic enzymes in molecular biology. Biomol Ther. 2013;3:923-42.

4. Rawlings ND, Barrett AJ, Finn R. Twenty years of the MEROPS database of proteolytic enzymes, their substrates and inhibitors. Nucleic Acids Res. 2016; 44(D1):D343-50

5. Schrader EK, Harstad KG, Matouschek A. Targeting proteins for degradation. Nat Chem Biol. 2009;5:815-22.

6. Rub A, Arish M, Husain SA, et al. Host-lipidome as a potential target of protozoan parasites. Microbes Infect. 2013;15:649-60.

7. Andrews KT, Fisher G, Skinner-Adams TS. Drug repurposing and human parasitic protozoan diseases. Int J Parasitol Drugs Drug Resist. 2014;4:95-111.

8. Silva-Barrios S, Stäger S. Protozoan parasites and type I IFNs. Front Immunol. 2017;8:14.

9. Di Genova BM, Tonelli RR. Infection strategies of intestinal parasite pathogens and host cell responses. Front Microbiol. 2016;7:256.

10. Leitsch D. Recent advances in the Trichomonas vaginalis field. F1000Res. 2016;5.pii:F1000 Faculty Rev-162.

11. Atkinson HJ, Babbitt PC, Sajid M. The global cysteine peptidase landscape in parasites. Trends Parasitol. 2009;25:573-81.

12. Sibley LD. The roles of intramembrane proteases in protozoan parasites. Biochim Biophys Acta. 2013;1828:2908-15.

13. López-Otín C, Bond JS. Proteases: multifunctional enzymes in life and disease. J Biol Chem. 2008:283:30433-7.

14. Drag M, Salvesen GS. Emerging principles in protease-based drug discovery. Nat Rev Drug Discov. 2010:9:690-701.

15. Deu $E$, Verdoes $M$, Bogyo M. New approaches for dissecting protease functions to improve probe development and drug discovery. Nat Struct Mol Biol. 2012;19:9-16.

16. Cerdà-Costa N, Gomis-Rüth FX. Architecture and function of metallopeptidase catalytic domains. Protein Sci. 2014;23:123-44.

17. Marshall NC, Finlay BB, Overall CM. Sharpening host defenses during infection: proteases cut to the chase. Mol Cell Proteomics. 2017;16:S161-71.

18. Cornick S, Chadee K. Entamoeba histolytica: host parasite interactions at the colonic epithelium. Tissue Barriers. 2017:5:e1283386.

19. Tillack M, Biller L, Irmer $H$, et al. The Entamoeba histolytica genome: primary structure and expression of proteolytic enzymes. BMC Genomics. 2007:8:170

20. Matthiesen J, Bär A-K, Bartels A-K, et al. Overexpression of specific cysteine peptidases confers pathogenicity to a nonpathogenic Entamoeba histolytica clone. MBio. 2013;4:e00072-13.

21. Ximénez C, González E, Nieves M, et al. Differential expression of pathogenic genes of Entamoeba histolytica vs E. dispar in a model of infection using human liver tissue explants. PLoS One. 2017;12:e0181962.

22. Bruchhaus I, Jacobs T, Leippe M, Tannich E. Entamoeba histolytica and Entamoeba dispar: differences in numbers and expression of cysteine proteinase genes. Mol Microbiol. 1996;22:255-63.

23. Serrano-Luna J, Piña-Vázquez $C$, Reyes-López $M$, et al. Proteases from Entamoeba spp. and pathogenic free-living amoebae as virulence factors. J Trop Med. 2013;2013:890603

24. Meléndez-López SG, Herdman S, Hirata K, et al. Use of recombinant Entamoeba histolytica cysteine proteinase 1 to identify a potent inhibitor of amebic invasion in a human colonic model. Eukaryot Cell. 2007;6:1130-6.

25. Kato K, Makiuchi T, Cheng X, Tachibana H. Comparison of hemolytic activity of the intermediate subunit of Entamoeba histolytica and Entamoeba dispar lectins. PLoS One. 2017;12:e0181864. 
26. Hellberg A, Nowak N, Leippe $M$, et al. Recombinant expression and purification of an enzymatically active cysteine proteinase of the protozoan parasite Entamoeba histolytica. Protein Expr Purif. 2002;24:131-7.

27. Quintas-Granados LI, Orozco E, Brieba LG, et al. Purification, refolding and autoactivation of the recombinant cysteine proteinase EhCP112 from Entamoeba histolytica. Protein Expr Purif. 2009;63:26-32.

28. He C, Nora GP, Schneider EL, et al. A novel Entamoeba histolytica cysteine proteinase, EhCP4, is key for invasive amebiasis and a therapeutic target. J Biol Chem. 2010;285:18516-27.

29. Zamudio-Prieto O, Benítez-Cardoza C, Arroyo R, Ortega-López J. Conformational changes induced by detergents during the refolding of chemically denatured cysteine protease ppEhCP-B9 from Entamoeba histolytica. Biochim Biophys Acta. 2014;1844:1299-306.

30. Lobstein J, Emrich CA, Jeans C, et al. SHuffle, a novel Escherichia coli protein expression strain capable of correctly folding disulfide bonded proteins in its cytoplasm. Microb Cell Factories. 2012;11:56.

31. Hashida S, Towatari T, Kominami E, Katunuma N. Inhibitions by E-64 derivatives of rat liver cathepsin B and cathepsin $L$ in vitro and in vivo. J Biochem. 1980;88:1805-11.

32. Baird $\Pi \mathrm{J}$ r, Wright WD, Craik CS. Conversion of trypsin to a functional threonine protease. Protein Sci. 2006;15:1229-38.

33. Que X, Kim S-H, Sajid M, et al. A surface amebic cysteine proteinase inactivates interleukin-18. Infect Immun. 2003;71:1274-80.

34. Hughes J, Rees S, Kalindjian S, Philpott K. Principles of early drug discovery. Br J Pharmacol. 2011;162:1239-49.

35. de Azevedo WF Jr, Soares MB. Selection of targets for drug development against protozoan parasites. Curr Drug Targets. 2009;10:193-201.

36. Fernández-Robledo JA, Vasta GR. Production of recombinant proteins from protozoan parasites. Trends Parasitol. 2010;26:244-54.

37. Wingfield PT. Overview of the purification of recombinant proteins. Curr Protoc Protein Sci. 2015:80:6.1.1-35.

38. Sambrook J, Fritsch EF, Maniatis T. Molecular Cloning: A Laboratory Manual. 2nd ed. New York, NY, USA: Cold Spring Harbor Laboratory; 1989.

39. Zor T, Selinger Z. Linearization of the Bradford protein assay increases its sensitivity: theoretical and experimental studies. Anal Biochem. 1996;236:302-8.

40. Leippe M, Sievertsen HJ, Tannich E, Horstmann RD. Spontaneous release of cysteine proteinases but not of pore-forming peptides by viable Entamoeba histolytica. Parasitology. 1995;111:569-74

41. Laemmli UK. Cleavage of structural proteins during the assembly of the head of bacteriophage T4. Nature. 1970;227:680-5.

42. Serrano JJ, de la Garza M, Reyes M, et al. Entamoeba histolytica: proteinase secretion induced by collagen type I is dependent on cytoskeleton integrity. Parasitol Res. 1996;82:200-5.

\section{Submit your next manuscript to BioMed Central and we will help you at every step:}

- We accept pre-submission inquiries

- Our selector tool helps you to find the most relevant journal

- We provide round the clock customer support

- Convenient online submission

- Thorough peer review

- Inclusion in PubMed and all major indexing services

- Maximum visibility for your research

Submit your manuscript at www.biomedcentral.com/submit

) Biomed Central 